\title{
Developing Character Education on Symbols of Begalan Tradition in Banyumas, Central Java
}

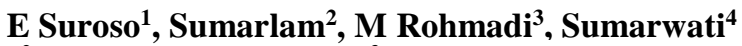 \\ $\left\{{ }^{1}\right.$ ekosuroso@ump.ac.id, ${ }^{2}$ sumarlamwd@gmail.com, ${ }^{3}$ rohmadi_dbe@yahoo.com/yuma_04ok@yahoo.com, \\ 4watik_uns@ymail.com\} \\ ${ }^{1}$ Universitas Muhammadiyah Purwokerto, Indonesia \\ ${ }_{1,2,3,4}$ University of Sebelas Maret Surakarta, Indonesia
}

\begin{abstract}
Symbols of Begalan tradition in Banyumas have numbers of great values for the development of character education (PPK). The problems arise later are 1) how is the tradition of begalan in Banyumas ?,2) how are the values of character education development implemented in the symbols of the Begalan tradition in Banyumas? This research was conducted with a qualitative descriptive approach. The data obtained were the symbols of the Begalan tradition in Banyumas district. The data collection techniques determined was observation and interview techniques. The observation technique was carried out to see directly how the Begalan tradition in Banyumas was performed. The interview technique was conducted to see how the origin and response of the people who carried out and saw the performances of the Begalan tradition in Banyumas. Data analysis was conducted by describing the symbols of the Begalan tradition in Banyumas and explaining the character values available in the Begalan tradition symbols. The results of the study indicated that there were some values of the symbols of the Begalan tradition in Banyumas which could be utilized to develop character education. Character values presented in the symbols of the Begalan tradition were 1) religious, 2) honest, 3) tolerance, 4) discipline, 5) hard work, 6) creative, 7) independent, 8) democratic, 9) nationalism, 10) respecting achievement, 11) friendly/communicative, 12) peace-loving, 13) environment care, 14) social care, and 15) responsible.
\end{abstract}

Keywords: implicature, Begalan Tradition in Banyumas, Character Values

\section{INTRODUCTION}

Banyumas is a district in central Java region which has a tradition called Begalan. When the saw the performance of Begalan tradition in Banyumas, the researcher saw kitchenware which was hung onto two "angkring" (many people calling brenong kepang). That is property of performance from four-legged bamboo. "brenong kepang" hung on two angkring and shouldered carried by one player. Other players play a role as a hijacker. From the statement of the actor, the researcher obtained that "uba rampe" and the "angkring" had an implicit meaning or in pragmatics known as implicature. Likewise, "uba rampe" brought by angkring, all of which have implicit meanings which is very appropriate for the development of human character education in general, and the development of the character of the groom and woman in particular. Begalan means to dispose bride and groom bad luck [1]. Habisch and Bachmann stated that there is an meaning to the implicit character reinforcement contained in the "begalan" show at Banyumas. The problem is now is what is the characters values from the show Begalan tradition in Banyumas? Thus, the 
study aimed to describe and explain the various values of characters which emerged from Begalan tradition in Banyumas.

Begalan Tradition is one of the distinctive features of the Banyumas wedding ceremony, which includes advice to the two brides symbolically conveyed and visualized in the form of drama fragments by two players [2]. A person portrayed himself as the envoy of the groom who carried angkring and uba rampe while another person served as a representative of the family of the bride who is in charge of the robber. In the angkring, there are housewares as the supplied by the bride and groom. According to Khan \& Bughio begalan means an attempt to rob the bride and groom's bad luck [3]. So the term ruwatan is included in the Begalan ceremony.

Character is personality, psychological traits, morals, or characters which distinguish someone from others [4]. Based on this understanding, characters can be positive or negative. However, based on Act No. 20 of 2018 concerning Strengthening Character Education article no 2 paragraph 1 , the character developed is a positive character. Characters developed in Act No. 20 is a character to the implementation of Pancasila values which consist of eighteen values, namely religious, honest, tolerant, disciplined, hardworking, creative, independent, democratic, curiosity, enthusiasm, nationality, love homeland, respect for achievement, communicative, peace-loving, bibliophile, environmental care, social care, and be responsible [5]. Therefore, the character values examined was the symbols of Begalan traditions in Banyumas which are available in character values of Pancasila (positive values) as mandated by Permendikbud No. 20 of 2018 relating to the Development of Character Education

\section{RESEARCH METHOD}

This study was conducted in qualitative descriptive approach. Therefore, the researcher describes, defines, and presents research data. In qualitative approach, researcher interpreted and explained to character values discovered in the research data [6]. The data of this study was obtained from Begalan tradition in Banyumas district. The data were collected from observation and interview techniques. The observation was implemented by looking directly at the performances of the Begalan tradition in Banyumas. The interview technique was done by the researcher interviewed players, organizers, and spectators of Begalan tradition. Interviews with players were carried out to obtain information about how the origin of the tradition was as well as the meanings of various tools used in the performance of Begalan tradition. Interview with the organizers was carried out to discover the motivation for organizing Begalan. Interviews with the audience were conducted to determine the benefits of Begalan tradition for the community, whether it was merely entertainment or there were certain character values internalized in people's lives. Data analysis was carried out by describing the Begalan tradition and explaining various character values found in Begalan tradition.

\section{RESULTS AND DISCUSSION}

\subsection{Begalan Tradition in Banyumas, Central Java}

Begalan is an art and form of traditional communication typical of Banyumas which has a long history. The art of Begalan was a work of Adipati Banyumas Raden Tumenggung Yudanegara IV (regent in colonial era) around the 1750s [7] [1]. It was originally created to dispose bad luck over the overthrow of itself as Regent of Banyumas which then had become part of the Banyumas culture and associated with wedding ceremony[8] [9]. At the moment, Begalan is a Banyumas culture carried out for generations and is believed by the community. Begalan can be referred to 
as a form of culture, both material and non-material. As Rido, Ibrahim, \& Nambiar stated that culture could be seen both materially and non-materially [10]. Material culture appears in material objects produced, then used by humans for example, simple tools such as accessories, household appliances, clothing, architectural design, computers and automotive [11]. Nonmaterial culture is the elements intended in the concepts of norms, values, beliefs, and languages. As a traditional culture, Begalan is a form habit or way of thinking displayed through the customs adopted by the Banyumas community. Folk culture according to Novianti was a model of indigenous communities characterized by economic activities for fulfilling their own needs, social intimacy among members, role of strength based on rituals and traditions, and relatively isolated from urban life [12].

Begalan comes from the Javanese word "begal" which means robbing or forcibly seizing in the middle of someone's journey. Mbegal or Begalan means imitating the way robbers block someone in the middle of their journey. In the area of the former residency of Banyumas, the word Begalan is known as an art show with the mission of giving marriage advice to the brides. Begalan's art began to perform on stage after Raden Tumenggung Yudanegara IV was deposed from his position by the British government as duke of Banyumas [11]. The duke of Raden Tumenggung Yudanegara IV as the 10th Duke of Banyumas aspired to have Banyumas to be independent as a private area (free of tax) or become an autonomous region, and no longer be a direct subordinate of the Surakarta Kasunanan (Empire). At that time, Kasunanan had begun to be subordinate to the Government of the Dutch. By the Surakarta Kasunanan, this dream was considered as mbalelo (rebel) to the government so that they were reported to the Dutch GovernorGeneral, and suggested to be sentenced with demotion from the Duke to become Mantri Anom. Regarding the report and proposal, the Dutch Governor General was welcome to realize and then determine his successor, namely Raden Tumenggung Yudanegara V as the 11th Duke of Banyumas. According to the story (Herusatoto, 2008), the former Duke of Raden Tumenggung Yudanegara IV was praying and obtained an inspiration to create Begalan art. The art was intended as a means for self-purification with the aim of removing the bad luck that happened to him so that he would soon get happiness and peace again, both for himself and his children and grandchildren. Begalan art in the form of tutur sembur (speech spray), which delivers a history of experience, ideas, and advice to children and grandchildren and relatives in order to be able to avoid things that cause bala (disasters). By the people of Banyumas, the art was then preserved and staged when carrying out hajat mantu kapisan (marrying the first daughter) with the aim of discarding suker (negative things that might hinder), which would hamper the new way of life for the bride and groom.

\subsection{Meanings of Begalan Tradition Tools in Banyumas, Central Java}

Begalan traditions use various tools. In Banyumas's terms, these are called uba rampe. The tool (uba rampe) is a media which present symbolic messages. The Uba rampe is a kitchen ware made entirely from bamboo, wood, and coconut shells. The types of uba rampe are: pari (paddy) and palawija (secondary crops), tepas (bamboo fan), kukusan (bamboo steamer), irus (ladle for soup), cething (rice basket), siwur (bamboo scoop for bath), enthong (ladle for rice), layah and ulegan (mortar and pestle), talenan (cutting boards), and dingklik (kitchen stool). All uba rampe are hung to angkring (double-legged bamboo). Angkring is a symbol of family independence which is able to stand alone. Both pair of angkring legs is a symbol of brides who is able to support all needs and burdens, which he carries out sincerely. Pari (paddy) and palawija (various kinds of yams) symbolize Dewi Sri, namely god of fertility and prosperity. Tepas (bamboo fan) has a double meaning, something which can be used to reduce hot and raise or burn the furnace fire in 
the kitchen. Irus helps to flip through or stir the vegetables which are being cooked so that the spices are evenly distributed. It symbolized that the case should be processed (reversed) and thought of as well as possible, not to take unilateral actions which will end in regret. Layah and ulegan symbolizes lingga (male/husband) and yoni (female/wife). Cething or bakul nasi is a symbol of fortune container. Kukusan is a place where paddy is cooked into rice. This is a description of the dynamic of life so that it is not to be directly occupied as it is, but take the steam (the implicit meaning of the dynamic). Siwur or Gayung helps to flush something (creating a cool atmosphere).

\subsection{Development of Character Values in Begalan Traditions}

Begalan literally means robbery by forcibly seizing the material of someone on the way of journey. In the context of Begalan tradition, membegal has the same meaning as the common word begal, but what is robbed (begal) is not the property but bajang sawan kaki penganten and nini penganten (the brides' bad luck) [13]. Pembegalan of bajang sawan is a manifestation to the development of the value of religious characters. The religious attitude referred to in this case is an effort to prevent other people from experiencing bad luck or getting danger. Angkring symbol presents a meaning of independence. The development of character education from the symbol [5] of angkring is a character of independence of a married person. This independence is also implicit as the development of responsibility in character education. The independent character referred to in this opportunity is independence in all things namely personality, social, and economic [14]. A married person is required to be independent as a form of his personal responsibility. Thus, the symbol of angkring is able to develop independent and responsibility characters. Pari symbol presents fertility. This symbol is able to develop the character of environmental care. Someone who does not care about the environment will not be able to create fertile plant to meet the food needs of his family. Palawija symbol means prosperity, which is implicitly able to develop a democratic and friendly character. In running a married life, one should be democratic in solving various problems. In order to make democracy working properly, a person needs to develop a friendly character because democracy without friendship will cause inconvenience[1]. If someone has a friendly character, it will automatically create an atmosphere of prosperity [13]. Tepas symbol presents cooling down the atmosphere which implies the development of the character of peaceful because peace will bring cold or cool atmosphere. Irus symbol utilized to take vegetables implies the development of creative character education. A man as a bread winner must be creative in order to be able to take the blessing of prosperity prepared by God Almighty on this earth. Layah and ulegan symbols presented as lingga (male/husband) and yoni (woman/wife) implicate the development of character of tolerance and democracy. Husbands and wives should be able to role as ulegan and layah, they must accept their respective positions, ulegan on the top and layah down. If they have accepted each other's positions, husband and wife can solve all problems democratically [15]. Settlement of the problem is illustrated with grinding chili, salt, union, and shrimp paste. Grinding (problem solving) really requires tolerance so that good democracy will occur. Kamaruddin said, a group of people will live peacefully if there is tolerance among them [9]. Cething symbol or bakul nasi is a symbol of a place (container) of fortune. This symbol has implications for developing the character of honesty and responsibility; it means that a wife, as a place for a husband to give the income, should be able to manage the income honestly and responsibly. Kukusan symbol used as a place to cook rice implies the development of creative characters and appreciates achievement. A wife must be creative to change paddy into rice so that it can be consumed (husband and wife). Besides, a husband must also be able to appreciate the achievements of his wife who has been able to turn paddy into rice. 
It supported by Scott-Phillips [16], they mentioned the slightest award to the slightest achievement will lead to a feeling of happiness like someone who respects it. Siwur Symbol utilized to water or flush plants means the development of environmentally friendly and socially caring character education. Husbands and wives must often water plants outside the home, meaning that paying attention, or caring to their neighbors. In addition, as the siwur functions to water plants, the wife and husband must also be able to maintain the environment and family [17].

\section{CONCLUSIONS}

Begalan tradition serves to develop religious character education. Angkring symbol illustrates the development of independence character education. Pari symbol describes the development of environmental care character education. Palawija symbol presents the development of democratic and friendly character education. Tepas symbol means cooling down or the development of the character of peaceful. Irus symbol whose function is to take vegetables illustrates the development of creative character education. Layah and ulegan symbol symbolize lingga (male/husband) and yoni (woman/wife) which implicate to the development of tolerance and democracy characters. Cething symbol is a symbol of a place (container) of fortune. It implies the development of honesty and responsibility characters; it means that a wife as a place for a husband to give income should be able to manage the income honestly and responsibly. Kukusan symbol utilized as a place to cook rice has implications for the development of creative characters and appreciates achievement. Siwur symbol used to water or flush plants contains the development of environmentally friendly and socially caring character education.

\section{REFERENCES}

[1] A. Habisch and C. Bachmann, "Empowering practical wisdom from religious traditions : a ricoeurian approach," Int. J. Corp. Soc. Responsib., pp. 1-9, 2016.

[2] J. Joseph and K. Alexander, "Personalizing the Wedding: A Cross-Cultural Study of Wedding Motivations in the Keralite Indian and Southern American Communities," p. 243, 2018.

[3] Q. Khan and F. A. Bughio, "Nunnery Scene: A pragmatic analysis of Hamlet-ophelia encounter," 3L Lang. Linguist. Lit., vol. 18, no. 2, pp. 25-34, 2012.

[4] B. Spector and Y. Sudo, Presupposed ignorance and exhaustification: How scalar implicatures and presuppositions interact? Springer Netherlands, 2017.

[5] A. Schwartz, "Reflections on 'Character Development' and the Journal of College and Character,” J. Coll. Character, vol. 9, no. 1, pp. 1-3, 2007.

[6] C. Hoyles, D. Küchemann, L. Healy, and M. Yang, "Students' developing knowledge in a subject discipline: Insights from combining quantitative and qualitative methods," Int. J. Soc. Res. Methodol. Theory Pract., vol. 8, no. 3, pp. 225-238, 2005.

[7] A. N. Kholifah and U. J. Soedirman, "Rendering Cultural Elements In Banyumasan Begalan :," vol. 9, no. 2, pp. 81-90, 2018.

[8] R. M. Ettekal, Andrea Vest; Burkhard, Brian; Ferris, Kaitlyn A.; Moore, Kristina L.; Lerner, "Character Education in High School Athletics: Perspectives from Athletics Directors on a Curriculum to Promote Character Development through Sport," J. Character Educ., vol. 14, no. 1, pp. 29-43, 2018.

[9] S. A. Kamaruddin, "Character Education and Students Social Behavior," J. Educ. Learn., vol. 6, no. 4, p. 223, 2012.

[10] A. Rido, N. Ibrahim, and R. M. K. Nambiar, "Interaction Strategies of Master Teachers in 
Indonesian Vocational Classroom : A Case Study," vol. 21, no. 3, pp. 85-98.

[11] L. Handayani, S. E. Nugroho, T. R. Rohidi, and Wiyanto, "The use of Banyumas traditional art as analog sources of elementary school science materials," J. Phys. Conf. Ser., vol. 983, no. 1, 2018.

[12] N. Novianti, "Teaching character education to college students using bildungsromans," Int. J. Instr., vol. 10, no. 4, pp. 255-272, 2017.

[13] M. F. Muttaqin and T. J. Raharjo, "The Implementation Main Values of Character Education Reinforcement in Elementary School," J. Prim. Educ., vol. 7, no. 1, pp. 103$112,2018$.

[14] T. Hariyanti and S. Sudjito, "Sustained Character Building Through Literature for College Students in Indonesia," J. Din. Huk., vol. 18, no. 1, p. 109, 2018.

[15] K. Saddhono and A. Kurniawan, "Islamic Religious Value in Traditional Ceremony of Begalan Banyumasan As Educational Character for Student At Senior High Schools in Central Java," Umr. - Int. J. Islam. Civilizational Stud., vol. 4, no. 1-1, pp. 71-77, 2017.

[16] T. C. Scott-Phillips, "Pragmatics and the aims of language evolution," Psychon. Bull. Rev., vol. 24, no. 1, pp. 186-189, 2017.

[17] B.W. Setyawan and K. Saddhono, "Eret traditional ceremony as representation of spirit of mutual cooperation among coastal communities". Adv. Sci. Let. vol. 23 no. 10, pp 99919992, 2017 